\title{
Effect of geothermal water composition and pretreatment on the product water for boron-sensitive crops
}

\author{
Enver Güler ${ }^{1 *}$ \\ ${ }^{1}$ Atılım University, Faculty of Engineering, Department of Chemical Engineering, Ankara, 06836, Turkey \\ ORCID orcid.org/0000-0001-9175-0920
}

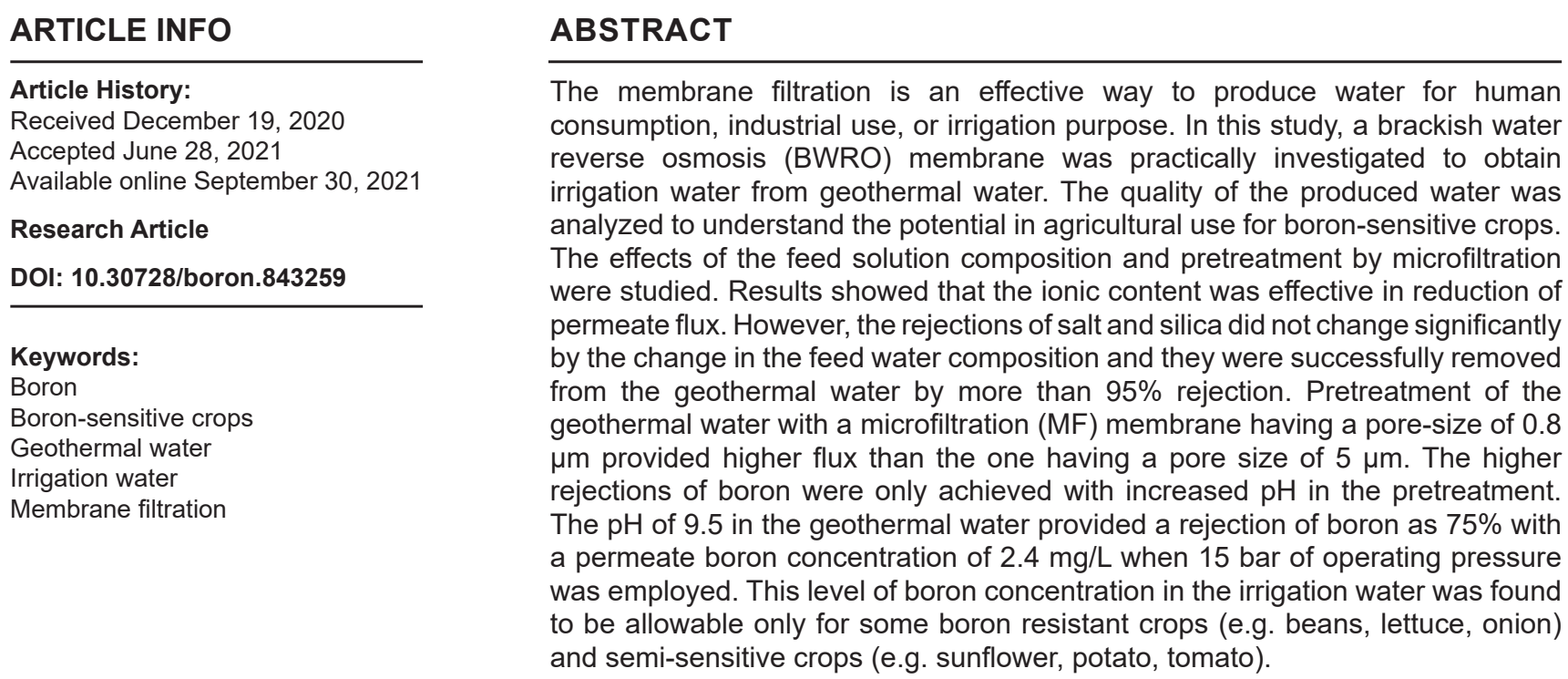

\section{Introduction}

Increasing demand related to agricultural production is directly proportional to living standards and global growth of population. This demand has been increased significantly specifically towards horticultural crops for a healthy lifestyle. Thus, the importance of irrigation water is felt deeply for arid and semi-arid areas where the water shortage is becoming an issue [1].

Irrigation water is vital for sustainable agriculture and should have some specific quality, such as lack of colloids, low salt content, and also low content of some trace elements like boron that may have severe adverse effects on horticultural productivity in the short and long term. This limits the direct use of natural water resources for irrigation purposes. Therefore, production of irrigation water or its treatment should be carefully performed to get rid of undesired contaminants.

In general, to obtain stream waters that can be directly used for irrigation is quite challenging in most of the areas in the world. Thus, brackish water becomes one of the most abundant supplies of irrigation water. Nevertheless, its treatment for irrigation is comparatively new in agriculture. The utilization of geothermal water as brackish water has taken excessive attention recently [2-6]. The mineral content of those resources may vary widely from $1 \mathrm{~g} / \mathrm{L}$ up to $200 \mathrm{~g} / \mathrm{L}$, which limits their direct use [7]. In the past, there have been several methodologies applied for the treatment and production of irrigation water from geothermal water. Most are task-specific techniques focusing on removal of particular species [5]. For instance, some include reverse osmosis (RO) and evaporation (for removal of dissolved solids [8]), oxidation and precipitation (for arsenic removal $[9,10]$ ), ion exchange (especially for boron removal/recovery [11-13]) and desilication by cooling ponds and soda ash (silica removal by soda ash or lime $[14,15])$. In addition, some integrated processes have been developed combining both ion exchange and membrane filtration for removal of boron and arsenic $[16,17]$. Each method has its own advantage considering the specific objective they have. However, RO, widely-used membrane process, have recently gained lots of attention due to the recently 
developed, cost-effective membranes and continuous mode of operations in both single and hybrid processes. Therefore, as an energy-efficient and easy to scale-up technology, the membrane processes such as $\mathrm{RO}$ are quite promising to provide product water with desired quality.

$\mathrm{RO}$ is the most widely studied membrane technology among all other alternatives $[18,19]$. Although up-todate RO membranes now can provide more than $99 \%$ of ionic rejection, retention of small and uncharged species is still a concern. At low pH values (lower than the dissociation constant of boron, pKa of 9.2), boron remains as very small uncharged species in aqueous media [20-24]. Thus, RO membranes perform less well and elevated $\mathrm{pH}$ is usually required in industrial desalination which is often limited by inorganic scaling (due to precipitation of calcium and magnesium compounds) as well. Moreover, when it is realized that the maximum allowable limit of boron in irrigation water is as low as $1 \mathrm{mg} / \mathrm{L}$, boron removal turns into a great challenge [25].

It is known that boron is a vital element for plant growth. The deficiency of boron in plants directly affects the stem and root systems and reduces metabolic activities. On the other hand, high boron concentrations cause toxicity presenting some signs especially in leaves such as discoloring and distortion [4]. The tolerance of crops usually varies up to $4 \mathrm{mg} / \mathrm{L}$ in irrigation water. Thus, available data on boron tolerances are recommended to be referenced when the use of irrigation water is the case for boron-sensitive crops. It is realized that most of the crops that have commercial value and also the ones required for a healthy lifestyle has some certain level of boron sensitivity. Very sensitive crops are citrus plants and some others like walnut, apple, and cherry, and can tolerate only up to $1 \mathrm{mg} / \mathrm{L}$ of boron in irrigation water. On the other hand, some crops have high resistance towards boron content in irrigation water (up to $4 \mathrm{mg} / \mathrm{L}$ ) such as beans, carrot, lettuce, and onion. Semi-sensitive crops which can tolerate $2 \mathrm{mg} / \mathrm{L}$ of boron concentration can be referred as sunflower, potato, tomato, wheat and corn.

One other issue on top of high boron content is the silica-containing water sources when it is considered for irrigation purposes. As silicon is very abundant element in the earth's crust, natural water sources usually contain silicon up to $40 \mathrm{mg} / \mathrm{L}$, even in some terrestrial regions its concentration can extent up to 100 $\mathrm{mg} / \mathrm{L}$ [26-30]. The concentration of silica $\left(\mathrm{SiO}_{2}\right)$ and its removal trend should be carefully monitored in $\mathrm{RO}$ systems. Hence, its concentration certainly affects the removal performance of boron as well. A certain level of silica naturally found in water streams such as in geothermal water may cause deposits or metal combinations on membrane surface. This is later inducted into silica fouling which is very difficult to remove. The existence of divalent cations such as calcium and magnesium promotes the precipitation of silica [31]. Silica fouling on RO membranes then results in significant flux decline reducing the water production capacity [32]. Therefore, not only the solution chemistry but also pretreatment or certain silica mitigation techniques should be realized before RO implementation.

In this work, the potential of a geothermal water source to be utilized for irrigation of boron-sensitive crops has been investigated. As operation parameters, the impacts of feed solution composition and pretreatment with microfiltration (MF) on the performance of a flat-sheet RO membrane were studied for removal efficiency of boron and silica by a commercial BWRO membrane.

\section{Materials and Methods}

\subsection{Materials and Chemicals}

\subsubsection{BWRO membrane}

The BWRO membrane commercialized by GE Osmonics is selected in this work due to high level of salt rejection properties. It is a thin-film polyamide-based membrane and represents a standard type of BWRO membrane in the industry. Specifications of the BWRO membrane employed were shown in Table 1.

Table 1. Specifications of the BWRO membrane [33].

\begin{tabular}{ll} 
Parameter & Specification \\
\hline Manufacturer & GE Osmonics \\
Material & Thin Film Material \\
$\begin{array}{l}\text { Typical Operating Pressure } \\
\text { Typical Operating Flux }\end{array}$ & $1.379 \mathrm{kPa}$ \\
$\begin{array}{l}\text { Maximum Operating Pressure } \\
\text { Maximum Operating }\end{array}$ & $3.103 \mathrm{kPa}$ \\
$\begin{array}{l}\text { Temperature } \\
\text { Operating Range pH }\end{array}$ & $50^{\circ} \mathrm{C}$ \\
$\begin{array}{l}\text { Maximum Pressure Drop } \\
\text { Over an element } \\
\text { Chlorine Tolerance }\end{array}$ & $4.0-11$ \\
$\begin{array}{l}\text { Feed water } \\
\text { Salt rejection minimum }\end{array}$ & $1,000+$ mg/L-hours \\
(NaCl) & \\
\hline${ }^{1}$ Average salt rejection after $24 \mathrm{~h}$ operation \\
${ }^{2}$ Testing conditions: $2,000 \mathrm{mg} / \mathrm{L} \mathrm{NaCl} \mathrm{solution} \mathrm{at} 1.551$ \\
kPa operating pressure, $25^{\circ} \mathrm{C}, \mathrm{pH} 7.5$ and $15 \%$ \\
recovery.
\end{tabular}

\subsubsection{MF membranes}

For pre-filtration of geothermal water, MF membranes with 5 and $0.8 \mu \mathrm{m}$ of pore sizes (Millipore Durapore, USA) were used in lab-scale flask type (vacuum-assisted) filtration unit. MF membranes do not have specific selectivity or affinity towards boron, silica and any other species naturally found in geothermal waters. 
Filtration is merely based on size exclusion. Specifications of MF membranes are shown in Table 2.

Table 2. Specifications of MF membranes.

\begin{tabular}{|c|c|c|}
\hline Parameter & $\begin{array}{c}5 \mu \mathrm{m} \\
\text { pore size }\end{array}$ & $\begin{array}{c}0.8 \mu \mathrm{m} \\
\text { pore size }\end{array}$ \\
\hline Wettability & Hydrophilic & Hydrophilic \\
\hline Filter Diameter, mm & 47 & 47 \\
\hline $\begin{array}{l}\text { Water Flow Rate, } \\
\mathrm{mL} / \mathrm{min} \mathrm{cm}^{2}\end{array}$ & 190 & 190 \\
\hline $\begin{array}{l}\text { Maximum Operating } \\
\text { Temperature, }{ }^{\circ} \mathrm{C}\end{array}$ & 85 & 75 \\
\hline
\end{tabular}

\subsubsection{Chemicals}

Determination of boron content in samples is performed by spectrophotometric Azomethine-H method. The chemicals used in this analytical method are Azomethine- $\mathrm{H}$ monosodium salt hydrate $\left(\mathrm{C}_{17} \mathrm{H}_{12} \mathrm{NNaO}_{8} \mathrm{~S}_{2}\right.$, Fluka), ascorbic acid (99\%, Acros Organics), ethylenediamine tetraacetic acid disodium salt dehydrate (EDTA, AnalaR, analytical grade), ammonium acetate $\left(\mathrm{CH}_{3} \mathrm{COONH}_{4}\right.$, Merck) and acetic acid $\left(\mathrm{CH}_{3} \mathrm{COOH}\right.$, $99-100 \%$, Merck). Boric acid $\left(\mathrm{H}_{3} \mathrm{BO}_{3}, 99.8 \%\right.$, Merck) and ultrapure water (Milli-Q) were used to prepare the standard solutions.

\subsection{Membrane Filtration Test System and Related Tests}

A lab-scale flat sheet membrane test unit (SEPA CF II GE Osmonics) has been employed for the filtration of the geothermal water. It allows the pre-simulation of industrial-scale membrane units. This cross-flow system is comprised of a membrane filtration cell equipped with a hydraulic assembly, high-pressure pump, and a feed tank. The pressure is controlled by a needle valve on the concentrate line and is measured by a manometer as a pressure indicator (PI). Figure 1 depicts the RO system employed.

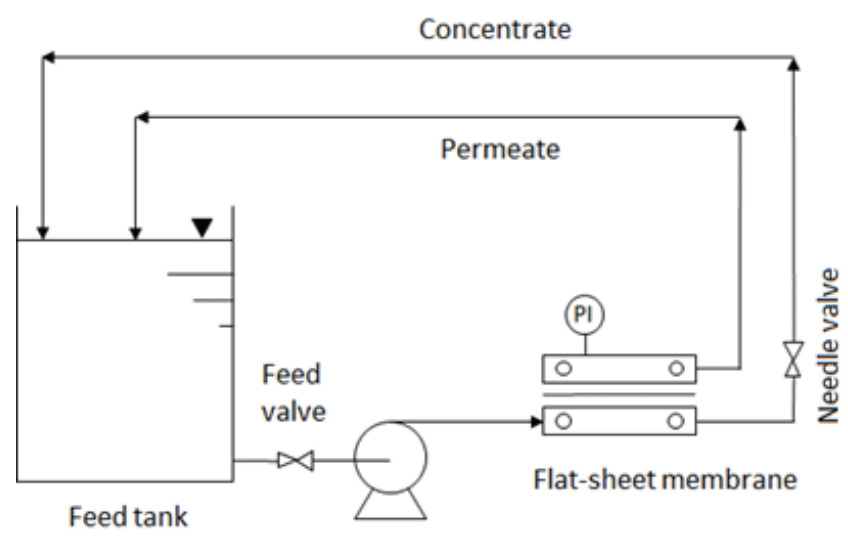

High-pressure pump

Figure 1. A representation diagram of the cross-flow flat-sheet membrane test system.

Before the RO operation, the membrane was immersed in the Milli-Q quality ultrapure water overnight.
The membrane filtration was continued for $8 \mathrm{~h}$. For each half an hour, flow rates, temperature, and total dissolved solids (TDS) were recorded, and samples were taken for the analyses of boron and silica at each one hour and two hours, respectively. In all tests, permeate and concentrate streams were re-circulated to the feed tank to maintain the feed content and volume constant to some extent.

\subsection{Vacuum-Assisted MF System as Pretreatment}

For pretreatment before the RO filtration of the geothermal water, a vacuum-assisted MF system was employed. A pressure/vacuum pump (Pall Life Sciences, USA) was used together with a glass-filter funnel (300 $\mathrm{mL}$ in capacity) where the geothermal water was fed. A flask with a capacity of $1 \mathrm{~L}$ was attached to a funnel where the filtrate was collected. The attachment was done with an aluminum clamp. Active filtration area was $9.6 \mathrm{~cm}^{2}$ that can be provided by $47 \mathrm{~mm}$-indiameter filter.

\subsection{Analytical Measurements}

A portable conductivity meter (Mettler Toledo, Switzerland) was used to measure TDS, conductivity, salinity, and temperature of water samples. A digital $\mathrm{pH}$ meter (WTW pH 315i/SET, Germany) was used for $\mathrm{pH}$ measurements.

A spectrophotometer (JASCO V-530 UVIVIS, Japan) was used for spectrophotometric boron analysis by Azomethine- $\mathrm{H}$ method. Analyses of silica concentrations were performed by Spectroquant Nova 60 (Germany) test kit using a spectrophotometer.

\subsection{Solute Rejection and Flux Calculations}

\subsubsection{Salt rejection}

Solute rejection, i.e. salt rejection, is defined as the ratio of solute (i.e. salt referred to as TDS in this work) that remains in the concentrate stream over the solute content in feed:

$$
S R=\left(1-\frac{C_{p}}{C_{f}}\right) \times 100
$$

In Eq. 2, SR is salt rejection in percent, $C_{p}$ and $C_{f}$ are solute concentrations (TDS) in permeate and feed side in $\mathrm{mg} / \mathrm{L}$, respectively. Boron and silica rejections are calculated in the same fashion using the concentrations that are analytically determined [34].

\subsubsection{Permeate Flux}

Permeate flux $(J)$ is calculated to observe any possible changes in filtration capacity of membranes. It is defined as volumetric flow per unit area [35]. Where $V_{p}$ is 
the permeate volume, $A_{m}$ is the membrane area used for filtration and $t$ is the filtration time.

$$
J=\frac{v_{p}}{A_{m} \cdot t}
$$

\subsection{Parameters Affecting the Performance of RO Membrane}

\subsubsection{Effect of the composition of the geothermal water}

Two different geothermal water samples, namely Sample-A and Sample-B, having different specifications were used as feed solution in the membrane filtration tests (Table 3). Ion content of sample waters was given in Table 4. Only major species were provided in tables eliminating the other trace ions that are naturally present. Cations were determined by atomic absorption spectroscopy (AAS), and anions were determined by ion chromatography (IC) except bicarbonate ion measured by titrimetric method. Boron and silica were measured by Azomethine- $\mathrm{H}$ and colorimetric methods, respectively. To protect the filtration system and membranes from the adverse fouling/scaling effects of natural geothermal water, filtration with a rough filter paper was employed. Then, using BWRO membrane, cross-flow RO filtration was performed at 15 bar providing an $800 \mathrm{~mL} / \mathrm{min}$ of feed flow.

Table 3. Characteristics of geothermal waters with different compositions.

\begin{tabular}{lcc}
\hline Parameters & Sample-A & Sample-B \\
\hline pH & 8.60 & 8.50 \\
Conductivity ( $\boldsymbol{\mu S / c m})$ & 1770 & 1854 \\
TDS (mg/L) & 885 & 926 \\
Salinity (\%o) & 0.700 & 0.930 \\
Turbidity (NTU) & 0.150 & 0.640 \\
Si (mg/L) & $56.0-65.0$ & $65.0-72.0$ \\
B (mg/L) & $10.3-11.0$ & $10.2-10.9$ \\
\hline
\end{tabular}

\subsubsection{Effect of MF pretreatment}

To investigate the effect of pretreatment with MF, two different MF membranes were employed with 5 and $0.8 \mu \mathrm{m}$ of pore-sizes for coarse and fine filtrations, respectively. After that, RO filtration with BWRO membrane was performed at 15 bar using $800 \mathrm{~mL} / \mathrm{min}$ of geothermal water as feed flow rate. For these set of experiments, the geothermal water named as Sample$B$, which has higher TDS than Sample-A, was used at its natural $\mathrm{pH}$ (8.5). Later, adjusted $\mathrm{pH}$ of 9.5 to realize the $\mathrm{pH}$ effect on microfiltration pretreatment was investigated for Sample-B as well. Vacuum-assistant filtration set up was used to investigate the effect of MF pretreatment.
Table 4. Ion content (mg/L) of geothermal water samples.

\begin{tabular}{lcc}
\hline Parameters & Sample-A & Sample-B \\
\hline $\mathrm{Na}^{+}$ & 366 & 364 \\
$\mathrm{~K}^{+}$ & 26.3 & 34.1 \\
$\mathrm{Ca}^{2+}$ & 26.2 & 12.1 \\
$\mathrm{Mg}^{2+}$ & 3.70 & 1.11 \\
$\mathrm{Cl}^{-}$ & 188 & 160 \\
$\mathrm{SO}_{4}{ }^{2-}$ & 109 & 185 \\
$\mathrm{~F}^{-}$ & 4.45 & 2.55 \\
$\mathrm{HCO}_{3}{ }^{-}$ & 622 & 635 \\
\hline
\end{tabular}

\section{Results and Discussion}

\subsection{Effect of feed water characteristics on RO per- formance}

Feed water specification is certainly a vital factor that affects the performance of the RO process. To investigate this impact, two different geothermal waters with different characteristics were selected. Tables 3 and 4 provide the brief data about these geothermal water sources that were filtered with a simple filter paper prior to RO filtration. Flux of the product water (permeate), rejections of boron and silica are calculated using a flat-sheet brackish water RO membrane. The applied pressure was 15 bar.

Permeate flux values calculated by Eq. 2 were calculated for two natural geothermal water samples during $8 \mathrm{~h}$ of the filtration test. Although $\mathrm{pH}$ of both samples was almost identical, their ionic compositions were different.

The similar trend of permeate fluxes was observed for both types of feed waters although the levels were different (Figure 2). It was possible to obtain a higher flux when Sample-A was used as feed. Although the presence of divalent cations in Sample-A is higher and

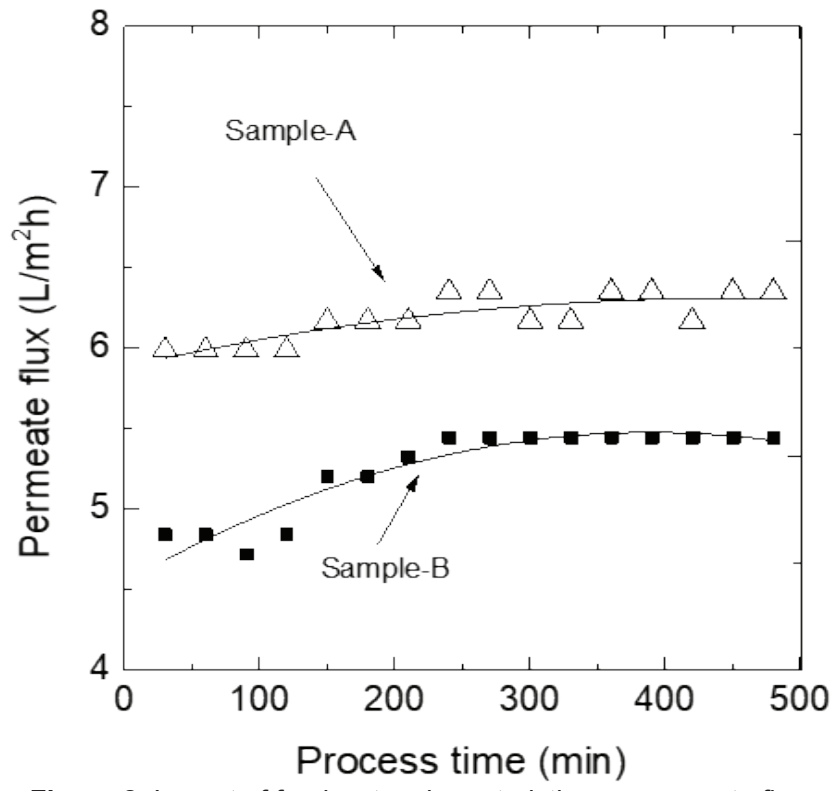

Figure 2. Impact of feed water characteristics on permeate flux. 
elevation of membrane scaling might be expected to rise, it was not an issue that affects the permeate flux. There is another hypothesis that these divalent ions contribute to neutralization of the membrane charge density and allow the rapid deposition of macromolecules which reduces the permeate flux through the membrane [36]. However, it was not the case either. The lower flux of Sample-B can only be attributed to the higher level of TDS (or high conductivity). Silica in Sample-B was also higher. Thus, total hardness (calcium and magnesium) might promote the deposition of silica on the membrane surface [37]. Therefore, silica fouling has great potential to be the basis to obtain lower levels of permeate flux.

In Figure 3, influence of feed water characteristics on salt, boron, and silica rejections was shown. Satisfying rejection levels of more than $95 \%$ for both feed samples were obtained for salt and silica. Nevertheless, the rejections of boron were lower (around 50\%). This was due to the relatively low $\mathrm{pH}$ of geothermal water samples at their natural state (Table 3). The acid dissociation constant of boric acid ( $\mathrm{pKa}$ ) is around 9.2 and higher $\mathrm{pH}$ levels can contribute to the existence of charged boron species and thus their retentions by membranes become easier. Boron at $\mathrm{pH} 8$ in groundwater is mostly found in the form of boric acid $\left(\mathrm{B}(\mathrm{OH})_{3}\right)$. It is a small, polar and uncharged molecule like water molecule. Elevation of $\mathrm{pH}$ above pKa promoted the transformation of boric acid to its negatively charged form, so-called borate $\left(\mathrm{B}(\mathrm{OH})_{4}{ }^{-}\right)$. Since most $\mathrm{RO}$ membranes today rely on charge and size based retention mechanisms to remove undesired species, increasing $\mathrm{pH}$ levels can certainly provide borate rejections as high as $99 \%[21,23,38]$.

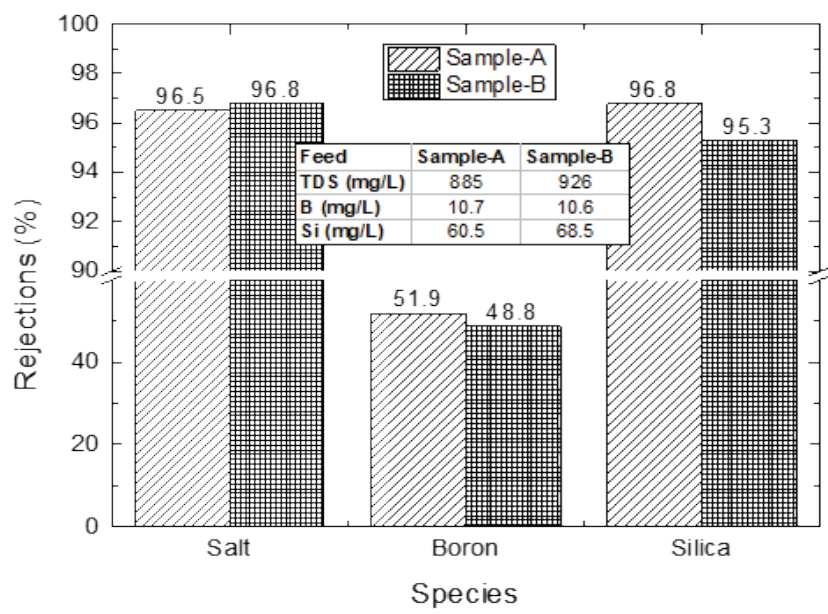

Figure 3. Impact of feed water characteristics on salt rejection.

Although the rejection values had minor differences when using two different geothermal water samples, it was observed that permeate of Sample-B had higher TDS value than that of Sample-A (Figure 4). The permeate TDS at the end of the operation was found as
$35.3 \mathrm{mg} / \mathrm{L}$ from the geothermal water having TDS of $926 \mathrm{mg} / \mathrm{L}$ (Sample-B). For Sample-A, the permeate TDS was found as $30.9 \mathrm{mg} / \mathrm{L}$ from the geothermal water containing TDS of $885 \mathrm{mg} / \mathrm{L}$. This shows that high TDS in the feed increases the dissolved solute level in permeate.

Even though the boron rejection for Sample-A was slightly higher than that for Sample- $B$, this difference did not contribute to a significant difference in the boron levels of the permeate samples at the end of operation. Boron concentrations in permeates of Sample-A and Sample-B were similar as 5.2 and 5.5, respectively (Figure 4).

Comparable retention behavior of silica like boron was observed when using Sample-A and Sample-B as feed waters. Nevertheless, silica was removed at high levels as more than $95 \%$ due to being less reliant on $\mathrm{pH}$, unlike boron (Figure 3). Thus, the silica concentrations in permeates of Sample-A and Sample-B were 2.2 and $2.6 \mathrm{mg} / \mathrm{L}$, respectively (Figure 4 ).

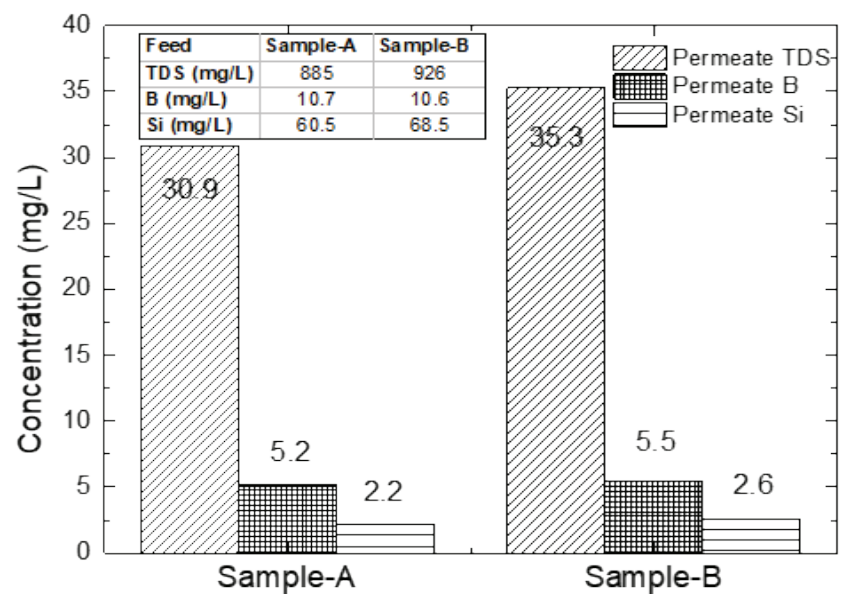

Figure 4. TDS, boron and silica concentrations in the RO permeates of different feeds at the end of operation.

Using RO membrane with 15 bar of filtration pressure provided permeates containing more than $5 \mathrm{mg} / \mathrm{L}$ of boron, which is not proper when considered as irrigation water for sensitive crops such as orange, lemon, apple, or grape. Standards for irrigation waters should be carefully checked when employing the RO permeate for agricultural irrigation because the level of boron is recommended as low as $1 \mathrm{mg} / \mathrm{L}$ in the irrigation water [25].

\subsection{Effect of MF Pretreatment on RO Performance at Natural $\mathrm{pH}$ of Geothermal Water}

MF is a physical pretreatment method of feed waters prior to the RO application. To investigate the effect of different filtration levels at natural $\mathrm{pH}$ of geothermal water, the feed geothermal water was filtered through coarse $(5 \mu \mathrm{m}$ pore size) and fine $(0.8 \mu \mathrm{m}$ pore size $)$ MF membrane filters. 
When the geothermal water was filtered by $0.8 \mu \mathrm{m}$ of MF filter, the RO membranes provided higher permeate fluxes (Figure 5). An average of approximately 7 $\mathrm{LMH}$ of a stabilized permeate flux was obtained during $\mathrm{RO}$ run after a fine pre-filtration whereas the respective value was $6 \mathrm{LMH}$ when a coarse pre-filtration was employed. The MF membrane was able to remove fine solids, silt, and some other particles. However, coarse filtration can be effective for removal of only coarser solids and suspended solids. Thus, those unrejected substances may deposit on the surface of the RO membrane, and reduce its efficiency resulting in a lower permeate flux. It was observed that the flux decline was not continuous during 480 min of operation. Yet there was a visible offset of flux levels between two $\mathrm{RO}$ tests due to coarse-and fine-filtered feeds prior to RO. It is also important to note that it took some time to level off the permeate flux for both feeds. This stabilization time was longer (up to $200 \mathrm{~min}$ ) when the coarse filtered feed was used for the RO system (Figure 4). This is a characteristic behavior for most membranes, thus membranes were soaked in ultrapure water beforehand to reduce this time,

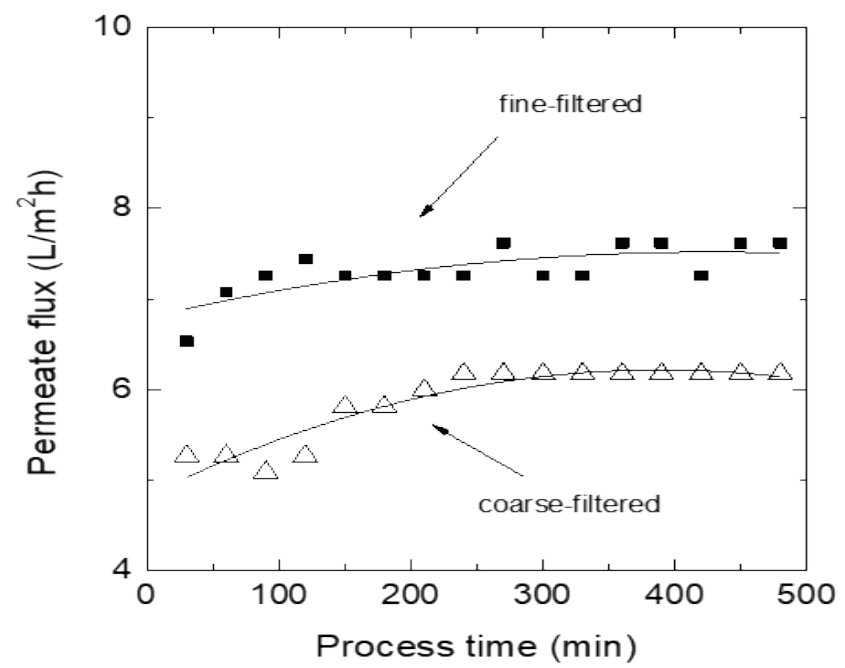

Figure 5. Effect of pre-filtration on permeate flux obtained by RO membrane at natural $\mathrm{pH} 8.5$.

When salt, boron, and silica rejections were calculated, it was found that fine-filtered feeds provided higher retention of salt and silica by the RO membrane (Figure 6). This may be attributed to the high efficiency of RO membrane with reduced fouling materials using fine filtering with a smaller pore size (i.e. $0.8 \mu \mathrm{m}$ ). However, this behavior was reversed in the case of boron removal. Slightly lower boron removal was obtained for fine-filtered feed. This may possibly be due to the colloidal matter remained after coarse filtration, which may promote adsorption of boron compounds or agglomerations resulting in easier removal by $\mathrm{RO}$ $[39,40]$. It was also realized that boron removals were significantly lower than salt and silica rejections at natural $\mathrm{pH}$ of geothermal water. This shows that natural

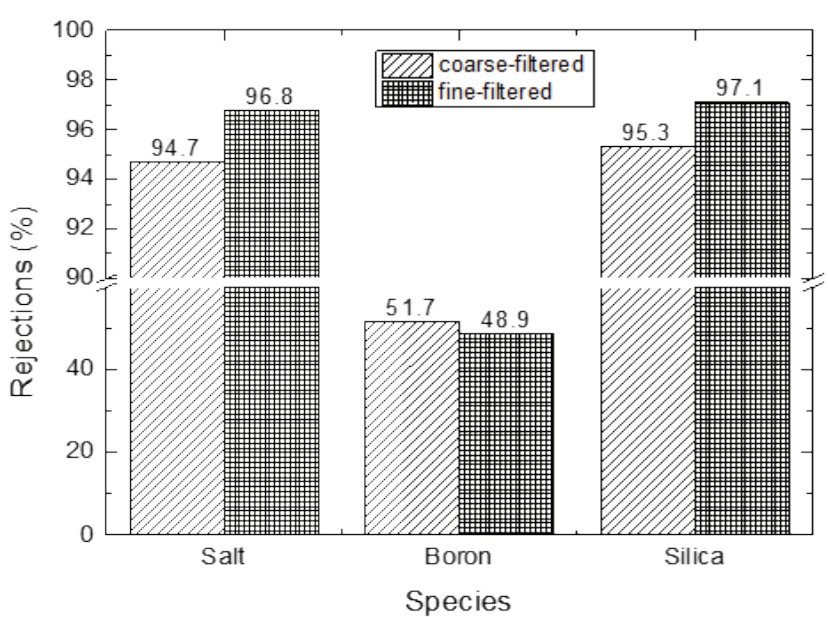

Figure 6. Effect of pre-filtration on salt, boron and silica rejections by $\mathrm{RO}$ membrane at $\mathrm{pH} 8.5$.

$\mathrm{pH} 8.5$ is low for efficient removal of boron.

Higher rejection levels of salt and silica for fine-filtered geothermal water provided lower concentrations of TDS and silica in the RO permeate samples as expected. In contrast, boron concentration in the RO permeate was higher for fine-filtered feed due to its lower rejection as indicated previously (Figure 7).

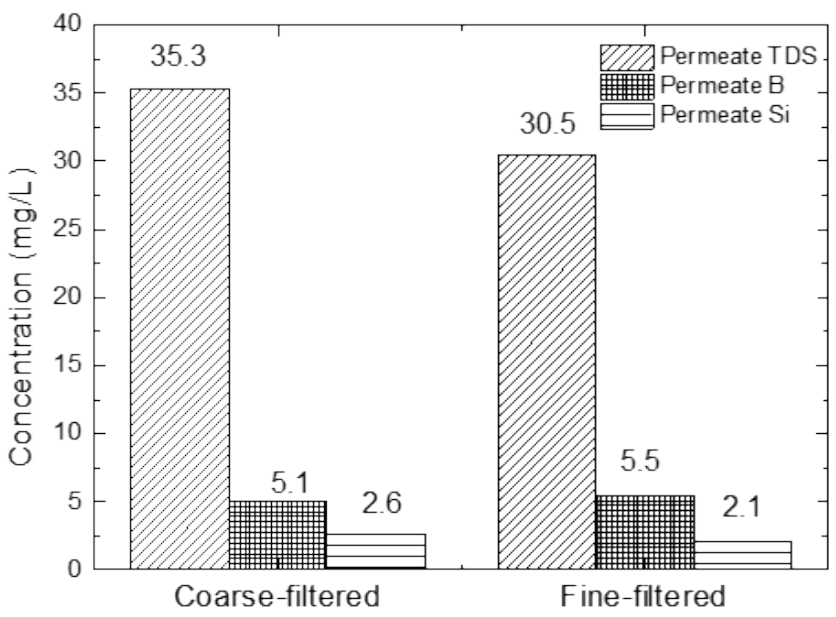

Figure 7. TDS, boron and silica concentrations of RO permeates at the end of RO operation using coarse-filtered and fine-filtered geothermal water samples at natural $\mathrm{pH}$.

Boron concentrations in the range of $5.1-5.5 \mathrm{mg} / \mathrm{L}$ are already much higher for irrigation of horticultural crops with high boron sensitivity (Figure 6). On the other hand, these boron levels may be acceptable for boron resistant crops although $4 \mathrm{mg} / \mathrm{L}$ is recommended as the uppermost concentration in irrigation water. This result recalls again the necessity of some process design towards the enhancement of removal efficiencies such as integration of RO with hybrid systems such as adsorption with membrane filtration or an effective $\mathrm{pH}$ adjustment. Effects of those parameters were previously shown $[41,42]$. 


\subsection{Effect of MF Pretreatment on RO Performance at Adjusted pH 9.5}

In certain cases, $\mathrm{pH}$ of the feed may be the issue in MF pretreatment before the $\mathrm{RO}$ operation. The $\mathrm{pH}$ of feed may vary or $\mathrm{pH}$ adjustment may be executed in some specific industrial RO systems. To better understand the effect of $\mathrm{pH}$ change before the MF pretreatment, $\mathrm{NaOH}$ solution was used to raise the $\mathrm{pH}$ of geothermal water (Sample-B) to 9.5. Then, the feed was filtered through coarse and fine MF membrane filters as discussed previously. After MF, cross-flow membrane set-up installed with BWRO membranes was operated at the same conditions (pressure: 15 bar; feed flow rate: $800 \mathrm{~mL} / \mathrm{min}$ ).

Both coarse-and fine-filtered feeds provided similar level of permeate flux of about $6 \mathrm{LMH}$ on average (Figure 8). However, flux stabilization behaviors were different: coarse-filtered feed provided fluctuating flux over $8 \mathrm{~h}$ whereas fine-filtered feed provided conventional stabilization trend as previously described. Fluctuating random flux values during operation might be the indication of initial scaling or fouling because higher levels of $\mathrm{pH}$ promote the calcium and magnesium-based scaling. This will later become the reason for flux decline for the prolonged RO operations. Nevertheless, averaged flux values were relatively lower when compared to the ones with natural $\mathrm{pH}$ reported in Figure 5.

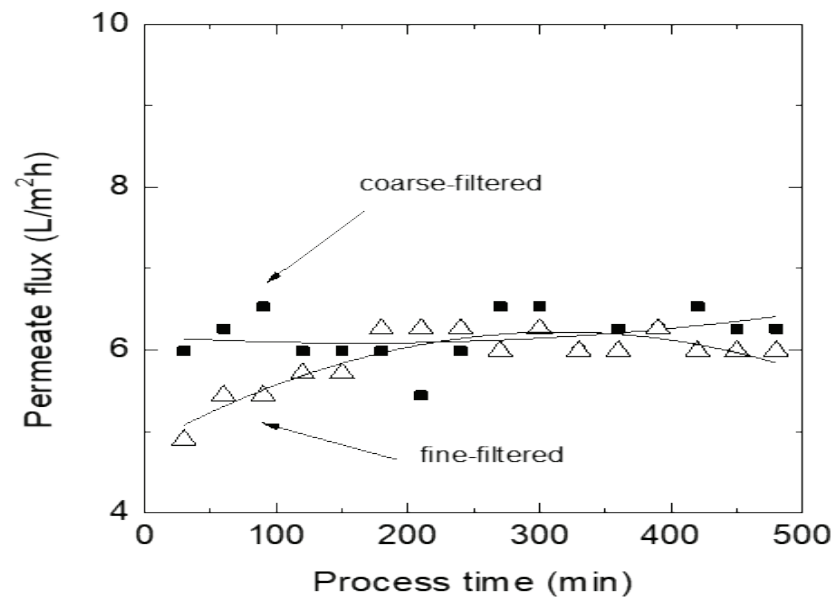

Figure 8. Impact of filtration on permeate flux at $\mathrm{pH} 9.5$.

It is also worth noticing that significant flux decline was not observed for both cases during $8 \mathrm{~h}$ of operation. This shows that the scaling issue was not yet critical, but longer operation periods may be required to observe the high $\mathrm{pH}$ effect on permeate flux. It was realized that hardness and alkalinity are two vital indicators of scaling. As calcium represents most of the total hardness, its concentration has to be monitored in feed water. Calcium concentrations in the geothermal waters used in this work were low compared to the concentration level where scaling concentrations typi- cally occur, i.e., 100 ppm hardness [43]. On the other hand, carbonate and hydroxide precipitations became pronounced at $\mathrm{pH}$ values of 9.3 and 10.5 , respectively [44]. In this case, high pH in the feed waters might be an issue. Although the kinetics of carbonate precipitation is assumed to be instantaneous, its deposition on membrane surface did not become severe to affect permeate flux within 8 hours as seen in Figure 8.

Increasing $\mathrm{pH}$ to 9.5 did not change the range of salt and silica rejections compared to natural $\mathrm{pH}$ of geothermal water (Figure 9). Besides, coarse and fine filtrations provided very similar salt and silica rejections at $\mathrm{pH}$ 9.5. Scaling at elevated $\mathrm{pH}$ of 9.5 was not the issue affecting any change. However, boron rejections increased from $50 \%$ to more than $70 \%$ due to high $\mathrm{pH}$ dependency. Similar to the situation at natural $\mathrm{pH}$, coarse-filtered feed delivered higher boron rejections compared to fine-filtration. This situation may be attributed to denser membrane surface due to particulate matter deposition that has potential for scaling, and boron-containing ionic compounds [45].

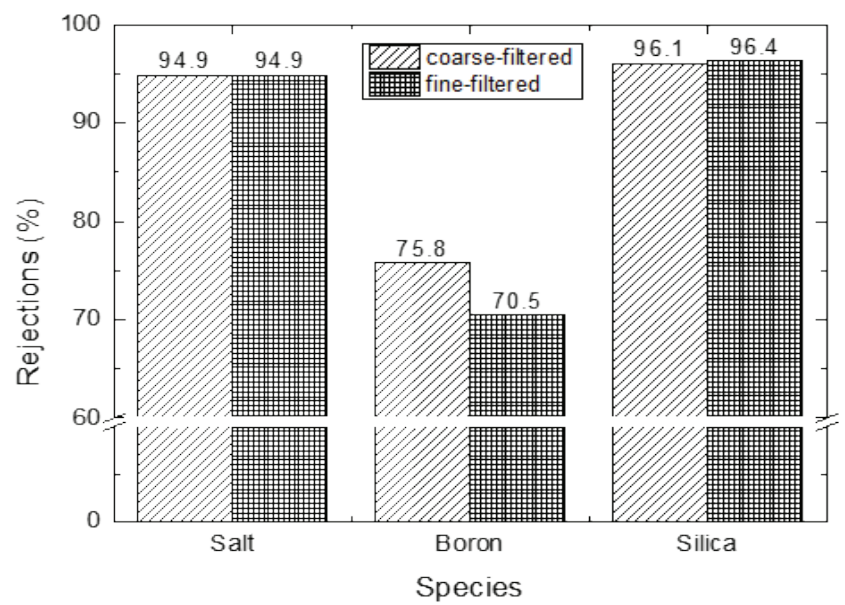

Figure 9. Effect of filtration on salt, boron and silica rejections at $\mathrm{pH} 9.5$.

At $\mathrm{pH}$ 9.5, the RO membrane performed stable rejections throughout the study lasting for $8 \mathrm{~h}$. Although salt and silica rejections were fairly in the same range, their concentrations in permeates obtained from both fine and coarse filtrated feeds were higher than the ones obtained at natural pH (Figure 10). Relatively high TDS in permeate was also a consequence of the $\mathrm{NaOH}$ added to the feed for $\mathrm{pH}$ adjustment. That means increasing $\mathrm{pH}$ slightly lowered membrane performance towards TDS and silica removals. The MF pretreatment can only help as mitigation of scaling factors to some extent, especially at elevated $\mathrm{pH}$ of feed waters. It was also good to realize that coarse filtration provided slightly better silica rejections thus lower permeate silica concentrations in permeate. This may be due the fact that silica probably polymerizes easily at the existence of $\mathrm{Mg}^{2+}$ and $\mathrm{Ca}^{2+}$ ions, thus not primarily removed by coarse filtration but subsequently better 
removed by the RO membrane afterward [31].

On the other hand, increasing $\mathrm{pH}$ increased boron removals resulting in lower boron concentrations in permeates (Figure 10). It was possible to obtain boron concentrations as low as $2.4 \mathrm{mg} / \mathrm{L}$. When irrigation water standards are considered, this concentration is still high but resistant or even some semi-sensitive crops can tolerate this level of boron. Conversely, the $\mathrm{RO}$ process should be developed further to produce appropriate irrigation water for sensitive crops at this stage. Increasing pH higher than 9.5 or implementation of hybrid processes (e.g. adsorption-membrane filtration systems) could help to provide lower boron concentrations $[41,46,47]$.

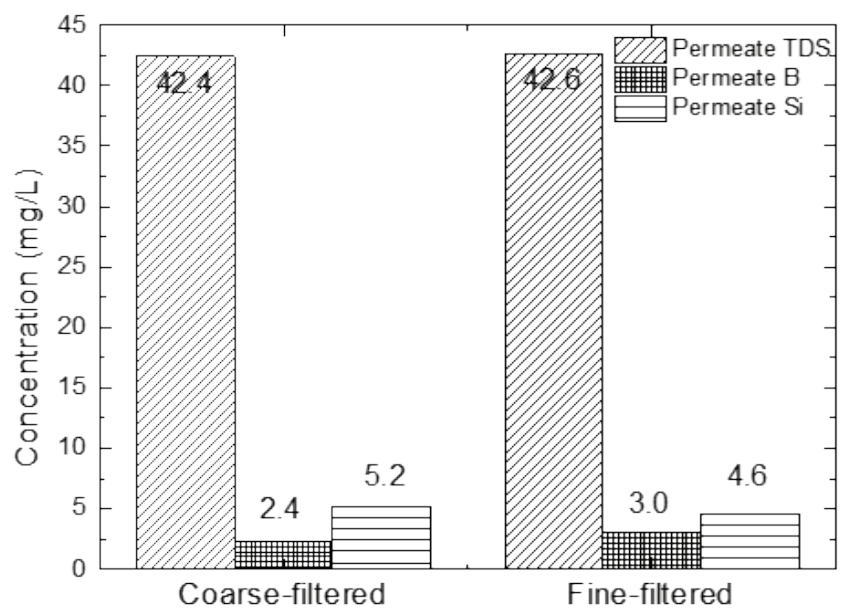

Figure 10. TDS, boron and silica concentrations of RO permeates at the end of operation using coarse-filtered and micro-filtered geothermal water samples at $\mathrm{pH} 9.5$.

\section{Conclusions}

The performance of a flat-sheet BWRO membrane to produce irrigation water from geothermal water for boron-sensitive crops has been investigated by analyzing the impacts of feed solution composition and MF pretreatment. The results showed that relatively high levels of TDS and silica in the feed was effective in lowering the permeate flux. The BWRO membrane was successful in retaining salt and silica but not boron at natural $\mathrm{pH}$. Also, different salt contents of the feeds used in this work did not change the boron concentrations in permeates significantly. It was also seen that choice of MF pretreatment filters is crucial. The choice of a smaller average pore size of $0.8 \mu \mathrm{m}$ (i.e. fine filtration) in the pretreatment promoted higher permeate flux in the RO membrane, and also higher rejections of salt and silica although boron rejection was not affected by the pore size of MF membrane. On the other hand, at elevated $\mathrm{pH}$ of 9.5 , coarse filtration (with $5 \mu \mathrm{m}$ pore size) provided improved rejections of boron resulting in $2.4 \mathrm{mg} / \mathrm{L}$ boron concentration in the RO permeate. The results suggest that the current experimental set-up operating at 15 bar with BWRO membrane can provide irrigation water for semi-sen- sitive and resistant crops only. Nevertheless, there is still room for the development of advanced RO processes either with hybrid assembly containing adsorption systems or with optimized process conditions.

\section{Acknowledgment}

The author is grateful to Prof. Dr. Nalan Kabay, Ege University for her valuable help to use the laboratory facilities and run the membrane tests. Furthermore, the author would like to acknowledge Izmir Geothermal Energy Co. for providing geothermal water samples.

\section{References}

[1] Lew, B., Tarnapolski, O., Afgin, Y., Portal, Y., Ignat, T., Yudachev, V. \& Bick, A. (2020). Irrigation with permeates to upgrade the quality of red pepper: a case study in Arava region, Israel. Environmental Technology, $1-11$

[2] Samatya, S., Köseoğlu, P., Kabay, N., Tuncel, A. \& Yüksel, M. (2015). Utilization of geothermal water as irrigation water after boron removal by monodisperse nanoporous polymers containing NMDG in sorptionultrafiltration hybrid process. Desalination, 364, 62-67.

[3] Koseoglu, H., Harman, B. I. I., Yigit, N. O. O., Guler, E., Kabay, N. \& Kitis, M. (2010). The effects of operating conditions on boron removal from geothermal waters by membrane processes. Desalination, 258(1-3), 7278.

[4] Yilmaz, A. E., Boncukcuoğlu, R., Kocakerim, M. M., Yilmaz, M. T. \& Paluluoğlu, C. (2008). Boron removal from geothermal waters by electrocoagulation. Journal of Hazardous Materials, 153(1-2), 146-151.

[5] Gallup, D. L. (2007). Treatment of geothermal waters for production of industrial, agricultural or drinking water. Geothermics, 36(5), 473-483.

[6] Öner, Ş. G., Kabay, N., Güler, E., Kitiş, M. \& Yüksel, M. (2011). A comparative study for the removal of boron and silica from geothermal water by cross-flow flat sheet reverse osmosis method. Desalination, 283, 10 15.

[7] Tomaszewska, B. \& Szczepański, A. (2014). Possibilities for the efficient utilisation of spent geothermal waters. Environmental Science and Pollution Research, 21(19), 11409-11417.

[8] Bourcier, W., Ralph, W., Johnson, M., Bruton, C. \& Gutierrez, P. (2006). Silica Extraction at Mammoth Lakes, California. International Mineral Extraction from Geothermal Brine Conference, Tiscon AZ, US, 1-6.

[9] Simmons, M., Gallup, D. \& Harden, D. (2002). Photooxidation, removal and stabilization of arsenic residuals in drinking water, wastewater and process water systems. Trends in Geochemistry, 2, 73-84.

[10] Yoshizuka, K., Kabay, N., \& Bryjak, M. (2016). Arsenic and boron in geothermal water and their removal, The Global Arsenic Problem (pp. 131-148). CRC Press.

[11] Recepoḡlu, O. \& Beker, Ü. (1991). A preliminary study on boron removal from Kizildere/Turkey geothermal 
waste water. Geothermics, 20(1-2), 83-89.

[12] Gallup, D. L. (1995). Agricultural uses of excess steam condensate: Salton Sea geothermal field. Geothermal Science and Technology, 4(3), 175-187.

[13] Badruk, M., Kabay, N., Demircioglu, M., Mordogan, H. \& Ipekoglu, U. (1999). Removal of boron from wastewater of geothermal power plant by selective ion-exchange resins. I. Batch sorption-elution studies. Separation Science and Technology, 34(13), 2553-2567.

[14] Gallup, D. K. \& Glanzman, R. K. (2003). Method for synthesizing crystalline magnesium silicates from geothermal brine (U.S. Patent No. US6761865B1). U.S. Patent and Trademark Office.

[15] Gallup, D. L., Sugiaman, F., Capuno, V. \& Manceau, A. (2003). Laboratory investigation of silica removal from geothermal brines to control silica scaling and produce usable silicates. Applied Geochemistry, 18(10), 15971612.

[16] Yanar, P. (2015). Investigation the lithium, boron and arsenic levels in Aegean region geothermal waters and selective seperation of these elements [M.Sc. thesis, Ege University] Council of Higher Education Thesis Center (Thesis Number 405320).

[17] Kabay, N., Yilmaz-Ipek, I., Soroko, I., Makowski, M., Kirmizisakal, O., Yag, S., Bryjak, M. \& Yuksel, M. (2009). Removal of boron from Balcova geothermal water by ion exchange-microfiltration hybrid process. Desalination, 241(1-3), 167-173.

[18] Bick, A., Gillerman, L., Manor, Y. \& Oron, G. (2012). Economic Assessment of an Integrated Membrane System for Secondary Effluent Polishing for Unrestricted Reuse. Water, 4(1), 219-236.

[19] Ozturk, O. F., Shukla, M. K., Stringam, B., Picchioni, G. A. \& Gard, C. (2018). Irrigation with brackish water changes evapotranspiration, growth and ion uptake of halophytes. Agricultural Water Management, 195, 142-153.

[20] Teychene, B., Collet, G., Gallard, H. \&Croue, J. P. (2013). A comparative study of boron and arsenic (III) rejection from brackish water by reverse osmosis membranes. Desalination, 310, 109-114.

[21] Jung, B., Kim, C. Y., Jiao, S., Rao, U., Dudchenko, A. V., Tester, J. \& Jassby, D. (2020). Enhancing boron rejection on electrically conducting reverse osmosis membranes through local electrochemical $\mathrm{pH}$ modification. Desalination, 476, 114212.

[22] Oo, M. H. \& Ong, S. L. (2012). Boron removal and zeta potential of $\mathrm{RO}$ membranes: impact of $\mathrm{pH}$ and salinity. Desalination and Water Treatment, 39, 83-87.

[23] Oo, M. H. \& Song, L. (2009). Effect of pH and ionic strength on boron removal by RO membranes. Desalination, 246(1-3), 605-612.

[24] Ipek, I. Y., Guler, E., Kabay, N. \&Yuksel, M. (2016). Removal of Boron from Water by Ion Exchange and Hybrid Processes. In Ion Exchange and Solvent Extraction (pp. 33-63). CRC Press.
[25] Al-Shammiri, M., Al-Saffar, A., Bohamad, S. \&Ahmed, M. (2005). Waste water quality and reuse in irrigation in Kuwait using microfiltration technology in treatment. Desalination, 185(1-3), 213-225.

[26] Al-Rehaili, A. M. (2003). Comparative chemical clarification for silica removal from RO groundwater feed. Desalination, 159(1), 21-31.

[27] Gorzalski, A. S. \& Coronell, O. (2014). Fouling of nanofiltration membranes in full-and bench-scale systems treating groundwater containing silica. Journal of Membrane Science, 468, 349-359.

[28] Sheikholeslami, R. \& Bright, J. (2002). Silica and metals removal by pretreatment to prevent fouling of reverse osmosis membranes. Desalination, 143(3), 255267.

[29] Neofotistou, E. \& Demadis, K. D. (2004). Use of antiscalants for mitigation of silica (SiO2) fouling and deposition: Fundamentals and applications in desalination systems. Desalination, 167(1-3), 257-272.

[30] Ning, R. Y. (2003). Discussion of silica speciation, fouling, control and maximum reduction. Desalination, 151(1), 67-73.

[31] Park, Y. M., Yeon, K. M. \& Park, C. (2020). Silica treatment technologies in reverse osmosis for industrial desalination: A review. Environmental Engineering Research, 25(6), 819-829.

[32] Piyadasa, C., Ridgway, H. F., Yeager, T. R., Stewart, M. B., Pelekani, C., Gray, S. R. \& Orbell, J. D. (2017). The application of electromagnetic fields to the control of the scaling and biofouling of reverse osmosis membranes - A review. Desalination, 418, 9-34.

[33] SUEZ eStore for Water Technologies \& Solutions (n.d.). Retrieved December 13, 2020, from https://estore.suezwatertechnologies.com/

[34] Singh, R. (2005). Hybrid Membrane System design and operation. Hybrid Membrane Systems for Water Purification. (pp-197-242), Elsevier.

[35] Mulder, M., \& Mulder, J. (1996). Basic principles of membrane technology. Springer Science \& Business Media.

[36] Wang, Y. N. \& Tang, C. Y. (2011). Protein fouling of nanofiltration, reverse osmosis, and ultrafiltration membranes-The role of hydrodynamic conditions, solution chemistry, and membrane properties. Journal of Membrane Science, 376(1-2), 275-282.

[37] Koo, T., Lee, Y. J. \& Sheikholeslami, R. (2001). Silica fouling and cleaning of reverse osmosis membranes. Desalination, 139(1-3), 43-56.

[38] Cengeloglu, Y., Arslan, G., Tor, A., Kocak, I. \& Dursun, N. (2008). Removal of boron from water by using reverse osmosis. Separation and Purification Technology, 64(2), 141-146.

[39] Yilmaz, A. E., Boncukcuoğlu, R. \& Kocakerim, M. M. (2007). A quantitative comparison between electrocoagulation and chemical coagulation for boron removal from boron-containing solution. Journal of Hazardous 
Materials, 149(2), 475-481.

[40] Pokrovsky, O. S. \& Schott, J. (2002). Iron colloids/organic matter associated transport of major and trace elements in small boreal rivers and their estuaries (NW Russia). Chemical Geology, 190(1-4), 141-179.

[41] Güler, E., Kabay, N., Yüksel, M., Yiğit, N. Ö., Kitiş, M. \& Bryjak, M. (2011). Integrated solution for boron removal from seawater using RO process and sorptionmembrane filtration hybrid method. Journal of Membrane Science, 375(1-2), 249-257.

[42] Kabay, N., Güler, E. \& Bryjak, M. (2010). Boron in seawater and methods for its separation - A review. Desalination, 261(3), 212-217.

[43] Geothermal Communities (n. d.). Chapter 4 - Chemistry of Thermal Fluids, Retrieved December 13, 2020, from https://geothermalcommunities.eu/elearning/ chapters

[44] Ayoub, G. M., Zayyat, R. M. \& Al-Hindi, M. (2014). Precipitation softening: A pretreatment process for seawater desalination. Environmental Science and Pollution Research, 21(4), 2876-2887.

[45] Chen, B., Li, F. \& Zhao, X. (2020). Boron removal with modified polyamide RO modules by cross-linked glutaric dialdehyde grafting. Journal of Chemical Technology \& Biotechnology, 96, 465-473.

[46] Güler, E., Kabay, N., Yüksel, M., Yavuz, E. \& Yüksel, Ü. (2011). A comparative study for boron removal from seawater by two types of polyamide thin film composite SWRO membranes. Desalination, 273(1), 81-84.

[47] Güler, E., Öner, Ş. G., Kabay, N. \& Yüksel, M. (2019). Effect of operational parameters for boron removal from geothermal water by reverse osmosis (RO) membranes. International Symposium on Boron-BORON2019, 885-890. 